\section{Personnel Service Newsletter Goes Online}

Taking advantage of the growing availability of web access to APSA members, the Personnel Service Newsletter will be available online beginning in June. PSNOnline will be accessible via the Association's web site in a fully searchable format to both individual subscribers and departments who are members of the Departmental Services Program. Access to the online Newsletter will be controlled by a username and password system defined to subscribers in the June issue of the Newsletter.

In planning over the past seven months, the pilot project has unfolded in two stages. Beginning in February, employers were asked to submit job announcements via a special online form. The material submitted via this form and then stored in a searchable online database, became the basis of both the electronic and paper versions of the Newsletter in March, April, and May. The second stage - the actual testing of the online Newsletter-began in early May with a selected test group that included individual subscribers, department chairs, Association officers, and members of the APSA Council.

The advantages of the online Newsletter are as great to departments as to the individual subscriber. The web-based Newsletter will provide greater flexibility by allowing for later deadlines, quicker production, and more timely availability of job listings. Further, job postings submitted via the web appear exactly as submitted, as they have not been rekeyed, but rather transferred electronically between the submission form and the published Newsletter.

During the pilot stage of this project, the online and paper editions of the Newsletter will continue to be available on the same day, allowing those who do not have access to the web notification of job openings at approximately the same time as online users. In the future, the Association will move to have the online version of the Newsletter updated on a weekly or bimonthy basis. Subsequently, subscribers may choose to have access to only the electronic Newsletter.

PSNOnline is made available in part by the assistance of $\mathrm{H}-\mathrm{Net}$, the Humanities and Social Sciences Online Network, located at Michigan State University.

For further information on the Newsletter and online developments, visit the Association's web site at www.apsanet.org or email psn@apsanet.org.

\section{PROceedings Demonstration at Annual Meeting}

APSA invites meeting participants to view a demonstration of PROceedings: Political Research Online, the Association's online collection of Annual Meeting papers, at the 1998 conference. The PROceedings web site (pro.harvard.edu), developed and maintained by William J. Ball of The College of New Jersey, will be on display in the Panel Paper Room in the Boston Marroitt-Copley Place throughout the Boston meeting.

PROceedings, a joint project of APSA and the Harvard University Library, debuted at the 1997 meeting in Washington, DC. Currently, the site, which has been active since last September, features 131 papers from the 1997 meeting. Visitors to the site can search for papers by author, title, or keyword, and download their selections in PDF using the Adobe Acrobat Reader (available free at www.adobe.com). The 1997 papers will be available until August 14, 1998, when they will be replaced by the 1998 papers. Papers for the 1998 meeting will be available starting August 17, and the contents of the site will be updated frequently between August 17 and September 3.

The Association has invited all 1998 paper authors to submit papers for posting to the PROceedings site. If you have not received an invitation to post your Annual Meeting paper, please contact the PROceedings project team, in care of Theresa Gubicza, at proceedings@ apsanet.org. Authors can submit papers via a web form, email, or disk to Bill Ball, Department of Political Science, The College of New Jersey, Hillwood Lakes CN 4700, Trenton,
NJ 08650-4700; Email: ball@tcnj. edu; http://pro.harvard.edu.

\section{APSA to Sponsor Research Support Poster Session}

As part of its 94th Annual Meeting, APSA will sponsor a poster session designed to bring political scientists and program representatives from major funding institutions together to discuss research support. The 1998 session follows a successful session at the 1997 meeting, the first of its kind offered by the APSA.

Many of the institutions that participated in the 1997 Research Support Poster Session will return in 1998, including the National Science Foundation and the National Endowment for the Humanities. APSA has invited a number of new institutions to participate as well, including the Nonprofit Sector Research Fund. The complete listing of participating institutions and representatives will appear in the Annual Meeting Final Program.

Kenneth Kolson, deputy director of the Division of Research \& Education at the National Endowment for the Humanities, will be available September 3-6 for private consultation about the NEH review process. To schedule a meeting time, contact him at KKolson@neh.gov.

Everyone coming to the meeting is encouraged to attend this poster session and take advantage of the opportunity to speak one-on-one with representatives of funding organizations and institutions. Topics addressed will include identifying promising funding opportunities, fulfilling application requirements, and rising to the top in the competitive proposal process.

For more information about the Research Support Poster Session, please contact Theresa Gubicza, tgubicza@apsanet.org.

\section{Travel Grants for 1998 Annual Meeting}

In 1998 the Association will again offer a limited number of travel grants for advanced graduate students attending the APSA Annual Meeting in Boston. Funded through 
the generosity of APSA members, the maximum award for any grant will be $\$ 300$ and must be used for travel to the meeting. Grants will be awarded in two categories: (1) international graduate students attending U.S. institutions and (2) advanced American graduate students presenting a paper or poster on the Program.

Applicants must complete a short application and submit a letter of support prepared by their department chair. Applications without a letter of support will not be considered. Applicants who are furthest along in their course of study will be given greatest consideration. Previous winner are not eligible.

Applications are available in PDF format on the APSA web site at www.apsanet.org/98AM/Travel/or by contacting Sean Twombly at twombly@apsanet.org. The deadline for receipt of completed applications is July 3 .

\section{Women's Caucus for Political Science to Host Reception for Women of Color Graduate Students}

The Women's Caucus for Political Science and its Women of Color Committee will host its fourth annual reception honoring women of color graduate students in political science Thursday, September 3, 1998 at $6: 30 \mathrm{pm}$ at the APSA's 94th Annual Meeting in Boston. The reception will be cosponsored by the National Conference of Black Political Scientists and the Committee on the Status of Latina/os in the Profession. All APSA members are cordially invited to attend.

The reception provides an occasion for graduate students and faculty from different universities to meet one another, share common interests, and discover the diversity of perspectives and research interests that women of color have in the profession. The Women's Caucus hopes that the event will help alleviate the isolation some women of color might feel and furnish the opportunity to discover colleagues whose scholarly and personal sup- port will enrich their work as political scientists.

\section{Pi Sigma Alpha Joins APSA in Recognizing Teaching; Sponsors Annual Meeting Panel}

Pi Sigma Alpha, the National Political Science Honor Society, recently announced its cosponsorship of APSA's teaching awards, beginning at the 1998 Annual Meeting. Since 1993 the Association has paid tribute to political science teachers whose own colleges and universities have selected them for institutionwide recognition with a special Annual Meeting Honors Reception. The 1998 event will take place on Wednesday, September 2 at 6:00 p.m. in Boston.

To shed light on the development of unconventional classroom teaching methods, $\Pi \Sigma A$ will present a panel at the Annual Meeting on using simulation techniques for teaching political decision making. "Simulating Politics: Bringing the Drama of Conflict into the Undergraduate Classroom" will be chaired by Jeremy D. Mayer of Kalamazoo College and will feature papers by Mayer; Marcia Weigel, Bowdoin College; Ashlyn Kuersten, Western Michigan University; and Christopher C. Joyner and Tamara Cofman Wittes, Georgetown University. The discussants are Claudia Orenstein of the drama department at Barnard College, and political scientist Eric Siegel of the University of California, Davis.
For more about Pi Sigma Alpha and its programs, including information on how to start a chapter of the honor society on your campus, please contact the national office at Pi Sigma Alpha National Office, 1527 New Hampshire Ave., NW, Washington, DC 20036; Phone: (202) 483-2512; Email: pisigmaa@erols.com, or visit their web site at http://www.apsanet.org/ $\sim$ psa.

\section{Sapiro Represents APSA at British Meeting}

Virginia Sapiro, Sophonisba P. Breckenridge Professor of Political Science at the University of Wisconsin, Madison attended the annual meeting of the British Political Studies Association (PSA) in April as the official representative of the APSA. Spairo, Program Chair for the 1998 APSA Annual Meeting, delivered the opening Plenary Session lecture, "A History of Political Action in the United States."

Sapiro's participation marks a further step in a growing collaboration between the APSA and PSA. As part of an agreed exchange program, official representatives of the PSA will attend the APSA meeting in Boston later this year to discuss further efforts. The first major effort of the collaboration was the inclusion of British graduate programs in the 1998-2000 edition of the APSA's Graduate Faculty and Programs in Political Science.

\section{National Teaching Award for Political Scientists to Be Given for Second Year}

Rowman \& Littlefield established the Rowman \& Littlefield Award for Innovative Teaching in Political Science in 1997 to recognize political scientists who have developed effective new approaches to teaching in the discipline. The award, which carries a $\$ 500$ stipend, will be presented at the 1998 Honors Reception at the APSA Annual Meeting. This year's recipient will be chosen by a committee consisting of L. Sandy Maisel, Colby College (Chair); Kent Portney, Tufts University; Susette Talarico, University of Georgia; Kim Zisk, Barnard College; and Sheilah Mann, APSA (ex-officio). The deadline for nominations was February 15, 1998. 